\title{
The marks that humans' leave are too often scars
}

\author{
Nandita Sushilkumar Kaushal ${ }^{1}$, Shrikrushna Vasant Chavan ${ }^{2 *}$, \\ Arundhati Gundu Tilve ${ }^{1}$, C. V. Hegde ${ }^{1}$
}

\begin{abstract}
${ }^{1}$ Department of Obstetrics and Gynecology, TNMC and BYL Nair Hospital, Mumbai, Maharashtra, India
${ }^{2}$ Department of Obstetrics and Gynecology, Government Medical College \& Hospital, Nagpur, Maharashtra, India
\end{abstract}

Received: 19 September 2020

Accepted: 29 October 2020

\section{*Correspondence:}

Dr. Shrikrushna Chavan,

E-mail: kisna7020@gmail.com

Copyright: (C) the author(s), publisher and licensee Medip Academy. This is an open-access article distributed under the terms of the Creative Commons Attribution Non-Commercial License, which permits unrestricted non-commercial use, distribution, and reproduction in any medium, provided the original work is properly cited.

\section{ABSTRACT}

Caesarean scar ectopics are the newest member of this obstetric emergency. Although rare, are associated with torrential haemorrhage. Gravida 3 para 2 with previous two caesarean sections with spotting per vaginum. Ultrasound showed a pregnancy embedded in the scar of previous caesarean section. MRI confirmed it. Beta human chorionic gonadotropin (HCG) was 15000 which dropped to 5000 after. An innovative approach was taken to laparoscopically evacuate the pregnancy. The products of conception were removed and the incision sutured so as to achieve haemostasis. Beta HCG was 15000 which dropped to 5000. Patient was haemodynamically stable and discharged on day 3. An innovative approach with skilled surgical technique not only decreased the morbidity but also avoided an unnecessary hysterectomy.

Keywords: Previous-caesarean, Scar-ectopic, Laparoscopy, B-human chorionic gonadotropin, Ultrasound

\section{INTRODUCTION}

Cesarean scar pregnancy (CSP) is a rare form of an ectopic pregnancy wherein the trophoblast invades a defective and thinned out myometrium in a scar which is remnant of a previous cesarean section. ${ }^{1}$ the incidence of CSP ranges from 1 in 1800 to 1 in 2216. The frequency of CSP is approximately $0.15 \%$, which constitutes $6.1 \%$ of all ectopic pregnancies in patients after at least one cesarean operation $(52 \%){ }^{2}$ The mean gestational age was $7.5 \pm 2.5$ weeks and the sign was vaginal bleeding without pain. $^{3}$

This condition can be dangerous for the women because of the related complications such as placenta previa or accreta, uterine rupture, and hemorrhage due to massively increased vascularity associated with its growth, poor contractility of lower segment; it needs an operative intervention, leading to increased maternal morbidity and mortality. ${ }^{4}$ Therefore, an early diagnosis is crucial to improve the proper management. Early detection of this phenomenon is possible as ultrasound quality has improved. ${ }^{5,6}$

\section{Typical features for CSP}

Typical features for CSP are 1) no gestational sac within the uterine cavity and cervical canal 2) visualization of the gestational sac and/or placenta in the cesarean section scar 3 ) very thin muscle layer between the gestational sac and the urinary bladder wall (from $1-3 \mathrm{~mm}$ to $4.6 \mathrm{~mm}$ ) and intensive vascularization around the scar. ${ }^{7,8}$

These criteria exclude other diagnoses, such as cervicoisthmic pregnancy, cervical pregnancy or inevitable spontaneous abortion. ${ }^{9}$ 3D USG precise spatial location of the gestational sac and assessment of its relationships with the urinary bladder wall and other structures of the lower pelvis. MRI useful in CSP, it enables accurate measurement of the distance between the urinary bladder, myometrium and gestational sac, and offers good visualization of the uterine cavity and cervical canal. ${ }^{10}$ 


\section{CASE REPORT}

Here, 28 years, G4P2L2A1 presented with; 2.5 months of amenorrhea and spotting per vaginum. She had previous 2 LSCS, 5 years and 2.5 years back respectively; followed by an abortion. On examination, per vaginal findings were suggestive of uterus-8-10 week's size.

USG non-viable 6-7 weeks pregnancy in the cervical scar (previous LSCS site) suggestive of cervical scar pregnancy, increased peripheral vascularity, $C R L=6-7$ weeks, diameter of $\mathrm{sac}=3.5 \mathrm{cms}$, no cardiac activity. Beta HCG $15294 \mathrm{miu} / \mathrm{ml}$

MRI: suggestive of ectopic scar pregnancy on the anterior wall of lower uterine segment.

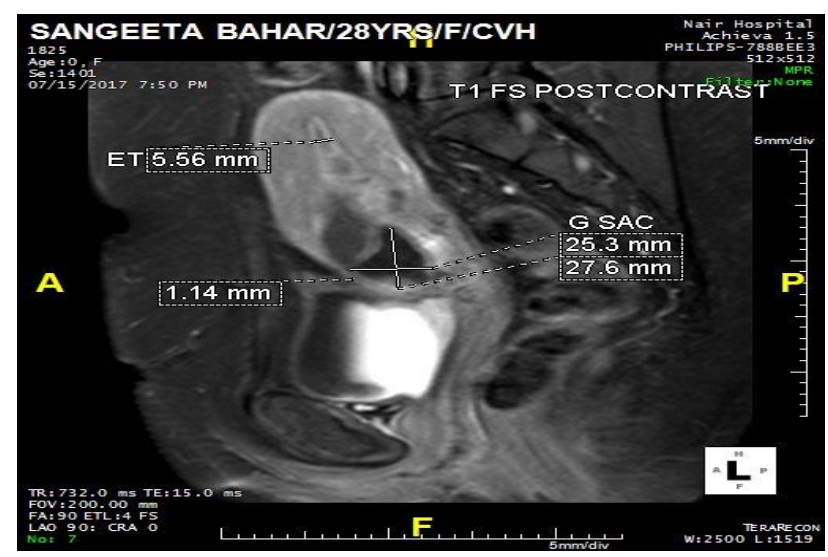

Figure 1: MRI showing G-sac.
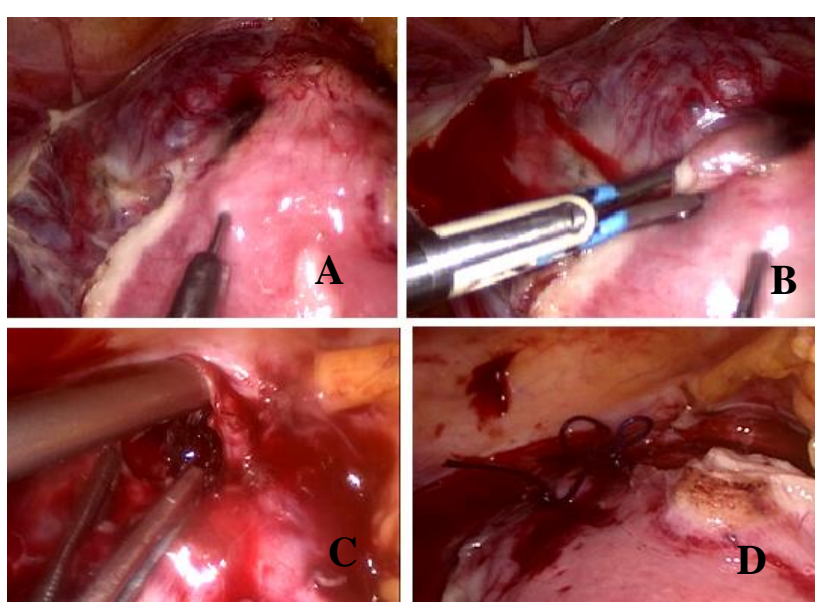

Figure 1: (A) vasopressin is injected into myometrium (B) uterine artery is coagulated (C) ectopic conceptus is being suctioned out (D) haemostasis achieved.

After due consideration it was decided to attempt a laparoscopic resection of the cesarean scar ectopic pregnancy. Intraoperatively, adhesions between bladder and anterior wall of uterus were released, following which diluted vasopressin was injected into the myometrium. The left sided uterine artery was seen close to the scar pregnancy and was opportunistically coagulated. The myometrium was then incised (Figure 2). The products of conception were removed and the incision sutured so as to achieve haemostasis.

Repeat serum beta HCG dropped down to $5550 \mathrm{miu} / \mathrm{ml}$ on day 3 post operatively. Patient was hemodynamically stable and was discharged on day 3 .

Section showed decidual tissue which is focally infarcted and few ghost chorionic villi. Focal aggregates of neutrophils are seen in decidual tissue. A repeat ultrasound day two revealed a small hematoma, repeat serum beta HCG dropped down to $5550 \mathrm{miu} / \mathrm{ml}$ on day 3 post operatively, patient had neutropenia, therefore, use of methotrexate was not advisable, patient was hemodynamically stable and was discharged on day 3 .

\section{DISCUSSION}

Conservative management includes using methotrexate, which is ideal for a caesarean scar ectopic pregnancy before 8 weeks gestation, with a beta HCG concentration of $<12000$.

Other treatment methods are recommended depending on their availability, intensity of symptoms and surgical skill: transvaginal resection, laparoscopy, $\mathrm{UAE}+\mathrm{D} \& \mathrm{C}+$ hyster-oscopy, $\mathrm{UAE}+\mathrm{D} \& \mathrm{C}$ and hysteroscopy. ${ }^{11}$ The combination of MTX+D\&C is the most effective and safe treatment for women in the early stages of pregnancy. The complication rate is overall reduced by an appropriate preoperative diagnostic ultrasound evaluation, identification of cases higher risk of complications and those eligible for a conservative treatment. The standard treatment has not been established in the management of scar pregnancy yet. However, the correct diagnosis and the personalized evaluation of risk factors could support physicians in making the best choice in terms of safety and efficacy.

\section{CONCLUSION}

Our case reinforces the importance of careful evaluation and prompt treatment of a patient with uterine scar pregnancy. Any combination therapy should be performed after due process taking into consideration the circumstances of the patient. As of now there is no fixed management protocol, each case has to be individualised.

\section{Funding: No funding sources \\ Conflict of interest: None declared \\ Ethical approval: Not required}

\section{REFERENCES}

1. Le A, Shan L, Xiao T, Zhuo R, Xiong H, Wang Z. Transvaginal surgical treatment of cesarean scar ectopic pregnancy. Arch Gynecol Obstet. 2013;287: 791-6. 
2. Ash A, Smith A, Maxwell D. Caesarean scar pregnancy. Int J Obstet Gynaecol. 2007;114:253-63.

3. Rotas MA, Haberman S, Levgur M. Cesarean scar ectopic pregnancies: etio $\neg \operatorname{logy}$, diagnosis, and management. Obstet Gynecol. 2006;107:1373-81.

4. Jurkovic D, Hillaby K, Woelfer B, Lawrence A, Salim R, Elson CJ. First-trimester diagnosis and management of pregnancies implanted into the lower uterine segment Cesarean section scar. Ultrasound in Obstetrics and Gynecology. J Int Soc Ultras Obstet Gynecol. 2003;21(3):220-7.

5. Moschos E, Sreenarasimhaiah S, Twickler DM. First-trimester diagnosis of cesarean scar ectopic pregnancy. J Clin Ultrasound. 2008;36:504-11.

6. Wlaźlak E, Surkont G, Shek KL, Dietz HP. Can we predict urinary stress incontinence by using demographic, clinical, imaging and urodynamic data? Eur J Obstet Gynecol Reprod Biol. 2015;193:114-7.

7. Vial Y, Petignat P, Hohlfeld P. Pregnancy in a cesarean scar. Ultras Obstet Gynecol. 2000;16:592-3.
8. Timor-Tritsch IE, Monteagudo A, Santos R, Tsymbal T, Pineda G, Arslan AA. The diagnosis, treatment, and follow-up of cesarean scar pregnancy. Am J Obstet Gynecol. 2012;207:44.e1-13.

9. El Guindi W, Alalfy M, Abasy A, Ellithy A, Nabil $\mathrm{A}$, Abdalfatah $\mathrm{O}$ et al. A report of four cases of caesarean scar pregnancy in a period of 24 months. J Med Diagn Meth. 2013;2:2.

10. Chiang AJ, La V, Chou CP, Wang PH, Yu KJ. Ectopic pregnancy in a cesarean section scar. Fertil Steril. 2011;95:2388-9.

11. Petersen KB, Hoffmann E, Larsen CR, Nielsen HS. Cesarean scar pregnancy: a systematic review of treatment studies. Fertil Steril. 2016;105(4):958-67.

Cite this article as: Kaushal NS, Chavan SV, Tilve AG, Hegde CV. The marks that humans' leave are too often scars. Int J Reprod Contracept Obstet Gynecol 2020;9:5163-5. 